\title{
CROP PROTECTION AND CONSERVATION OF FRUGIVOROUS BATS IN ORCHARDS OF HILL AND COASTAL REGIONS OF KARNATAKA
}

\author{
A.K. Chakravarthy and A.C. Girish \\ Department of Entomology, Regional Research Station, V.C. Farm, Mandya, Karnataka 571405, India.
}

\begin{abstract}
Two species of frugivorous bats, viz., Pteropus giganteus and Cynoptera sphinx were implicated in damaging sapota and guava fruits in hill (Chettalli) and coastal (Uppinangadi) regions of Karnataka. At Uppinangadi, the population of Pteropus giganteus ranged between 3500-4000 and Cynopterus sphinx, two to 28. Pteropus giganteus caused on an average $18 \%$ fruit losses in arecanut (Areca catechu). At Chettalli, damage to sapota (Achrus zapota) by Pteropus giganteus ranged between 12.50 to 22.30 from September to February 2000. Peak fruit damage to guava by bats was observed during August, when on an average $28 \%$ fruits were damaged. Despite damage to fruits and nuts of cultivated trees bats need to be conserved for their important ecological roles in cultivated ecosystems.
\end{abstract}

\section{Keywords}

Conservation, crop protection, frugivorous bats, fruit orchards, Karnataka, Western Ghats

\section{Introduction}

Bats and other lesser-known taxa have received little protection and face considerable threats and higher rates of endangerment. India's bat fauna is rich and diverse with 114 species (17 megachiroptera \& 97 microchiroptera) which is more than $11 \%$ of the world's bats (Bates \& Harrison, 1997). However, the Chiropteran diversity in the Indian subcontinent is presently represented by 123 species belonging to 37 genera and eight families, with 114 species belonging to 33 genera and eight families within Indian limits (Molur et al., 2002). These species provide substantial ecological and economic services via pollination, seed dispersal and agricultural pest control (Mistry, 2001). For example, the common species of fruit bats (Cynopterus sphinx, Pteropus giganteus and Rousettus leschenaulti) visit over 114 plant species and act as important pollen and seed vectors (Mickleburgh et al., 1992; Molur et al.,
1998). On many oceanic islands, fruit bats are the only animals capable of carrying large seeded fruits and can be the single most important pollinators, seed dispersers and 'keystone species' (Cox et al., 1991). At least 443 plant products useful to man are derived from 163 plant species that rely to some degree on bats for pollination or seed dispersal (Fujita \& Turtle, 1991). It is suffice to mention here that the beneficial effects of bats outweigh harmful effects. Due to loss of habitats and conflicts between bats and fruit growers (Jacobson \& Duplessis, 1976), there is a population decline of bats in recent years. It is for this reason, that maximum protection to fruit crops from damage caused by bats and birds is required. So an action plan for the conservation of fruit bats is of high priority (Mickleburgh et al., 1992). Yet many bat species in India face numerous threats. They may cause economic loss while feeding on fruits (Verghese, 1998; Srinivasulu \& Srinivasulu, 2001). In order to assess the damage and propose conservation measures for bats, a study was undertaken at two locations in Karnataka. Guava (Psidium guajava), Sapota (Achras zapota), Banana (Musa paradisiaca), Litchi (Litchi chinensis), Jack (Artocarpus indica) and Mango (Mangifera indica) orchards and Cashew (Anacardium occidentale) and Arecanut (Areca catechu) plantations are frequently visited by bats. The bats roosting in huge colonies were observed to be feeding on fruits, flowers and pollen, either by biting off and swallowing mouthful of fruits or crushing the fruit and swallowing or siphoning the juice, spitting out the pulp.

\section{Methods}

Bats were observed in Uppinangadi $\left(11^{\circ} 59^{\prime} \mathrm{N}, 75^{\circ} 17^{\prime} \mathrm{E} ; 181 \mathrm{~m}\right)$ in coastal region and Chettalli in hill region $\left(11^{\circ} 56^{\prime} \mathrm{N}, 75^{\circ} 22^{\prime} \mathrm{E}\right.$; $310 \mathrm{~m})$. The roost selected for observations at Uppinangadi consisted of trees such as Banyan (Ficus religiosa), Jack, Rain Tree (Samanea saman), Teak (Tectona grandis), Shisam or Sisoo (Dalbergia sisoo), Dhaman or Dhamni (Triewea nudiflora), Mango and Tamarind (Tamarindus indicus). The roosting site at Chettalli consisted of Banyan, Jack, Rain Tree and Mango.

Fruit losses were estimated by recording number of fruits 
Table 1. Pattern of Sapota damage by vertebrate pests at different months in Chettalli.

\begin{tabular}{llllll}
\hline Month & $\begin{array}{l}\text { Days } \\
\text { observ. }\end{array}$ & $\begin{array}{l}\text { Fruits damaged by } \\
\text { Bats }\end{array}$ & $\begin{array}{l}\text { Total fruits } \\
\text { damaged }\end{array}$ & $\begin{array}{l}\text { Avg. Fruit } \\
\text { damaged / day } \\
\text { I month }\end{array}$ \\
\hline Sep. 1999 & 1 & 11 & 11 & 22 & 22.0 \\
Oct. & 0 & 7 & 13 & 20 & 20.0 \\
Nov. & 6 & 75 & 95 & 170 & 16.4 \\
Dec. & 31 & 241 & 146 & 387 & 12.5 \\
Jan. 2000 & 15 & 165 & 110 & 275 & 18.3 \\
Feb. & 28 & 401 & 223 & 624 & 22.3 \\
Mar. & 18 & 28 & 16 & 44 & 2.4 \\
\hline
\end{tabular}

damaged to total number of fruits present at weekly intervals. Monthly surveys were conducted on four wheelers to identify the nature, extent of damage, habitat preferences of bats and to estimate crop loss. The population of bats was estimated by counting the number of bats visiting the orchards at dusk (1800 to $1900 \mathrm{hr}$ ), night (2200 to $2300 \mathrm{hr}$ ) and dawn (0500 to $0600 \mathrm{hr}$ ) by four observers with a $8 \times 30$ binoculars. Each observer was stationed at vantage points that had clear view of their sections. The observers counted bats approaching the orchards from four directions. The bats were counted at weekly intervals from July 1996 to March 1997, when damage assessments were also carried out and continued in 1999 and 2000. $X^{2}$ and ' $t$ ' tests were used to find statistical differences between means for population and fruit damage at monthly intervals.

\section{Results and Discussion}

At Uppinangadi, on an average, an Indian Flying Fox (Pteropus giganteus) a fruit eating bat, carried nine sapota fruits per visit mostly during the early part of dusk and morning. Cashews were eaten by Pteropus giganteus during the early fruiting period (January - February). The data on the population of Pteropus giganteus monitored during early dusk, night and early morning is presented in Figure 1. The population count of the roost at late evening hours of Pteropus giganteus ranged between 35004000 individuals. The bat population gradually declined from 4000 in 1994 to 2500 in 1999, there being significant differences between the two counts by $X^{2}$ test $(\mathrm{P}>0.005)$. The bat population remained at 3000 at roost during 1996 and 1997. The population size of Short-nosed (Indian) Fruit Bat (Cynopterus sphinx) varied from two to 28 in a 30-acre banana plantation. The temporary roosting sites of Pteropus giganteus and Cynopterus sphinx were also located in caves, buildings and on trees like teak. The foraging of bats at Areca gardens was observed during late evenings. About 25 to 30 Pteropus giganteus visited the garden

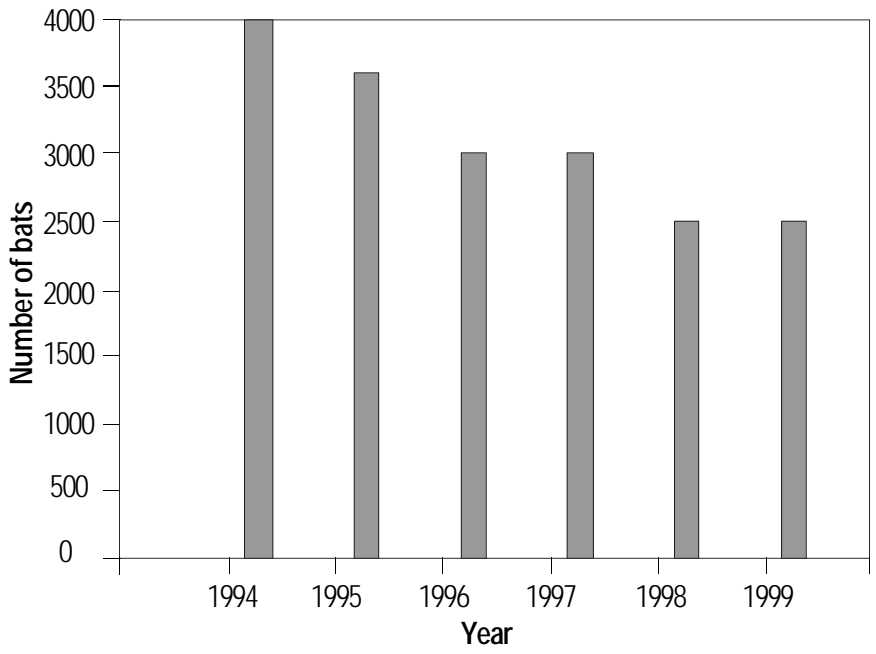

Figure 1. The status of Indian Flying Fox (Pteropus giganteus) at Uppinangadi, Dakshina Kannada from 1994-1999

and plucked Areca fruits. Damage to Areca fruits started from November and the damage was severe and economically important (fruit loss @ 38/day for 18 days). An estimation on nut losses revealed that Pteropus giganteus caused on an average $18 \%$ losses in fruits ( $\mathrm{n}=30$ observations). Highest mortality of young Pteropus giganteus were observed during March when on an average 11 young bats were found on the ground under roosting trees. The peak breeding period of Pteropus giganteus was observed during March. During 1997 and 1998 death of 50 to 70 individuals was recorded at the roosting sites. Due to constant faecal droppings, the foliage of trees underneath roost trees was destroyed and foul smell emanated from the roosting site. The droppings of Cynopterus sphinx was observed to destroy young (1-2 years old) seedlings. In the hill region, the feeding of Cynopterus sphinx and Pteropus giganteus in orchards like that of guava and sapota and plantations like that of coffee and cashew was seasonal and much of the seasonal movement was in the northwesterly direction, where most of the fruit orchards were concentrated. Bat damage to fruit was invariably associated with bird damage. On 25 sapota trees observed at Chettalli, birds damaged 252 fruits and bats 146 fruits of the total 4816 fruits, with an average loss of $13.02 \%$ to the sapota crop in December 1999. Peak fruit damage was observed in February 2000 where 401 sapota fruits were damaged by birds and 223 by bats (Table 1). The percent fruit damage ranged between 12.5 to 22.3 from September to February 2000, there being statistical significant differences between the two means by ' $t$ ' test $(\mathrm{P}>0.005)$. From March the damage percent declined drastically as fruit production also became negligible. In general, in guava and sapota orchards as the number of observations increased the number of fruits damaged increased but percent fruit damage 
decreased. The birds punctured the fruits by sharpened beaks and fed on the internal sweet pulp or contents leaving the markings of their beak on the fruit. Whereas the bats chewed the pulp of the fruits, be it guava or sapota only juice or pulp was sucked and the solid substance was rejected. The fruit damage can be distinguished by their teeth (incisors) markings seen as narrow canals or grooves on the fruits, covering more fruit surface superficially. The bat damage to sapota fruits occurred throughout the fruiting season i.e. from September 1999 to March 2000 while the bird damage occurred from November 1999 to March 2000 in a sapota orchard at Chettalli. This suggests that bats are incurring losses by damaging even unsized and unripened fruits. Bats fed on guava fruits from July to February. Peak fruit damage to guava by bats was observed during August, when on an average $28 \%$ fruits $(\mathrm{n}=$ 58) were damaged per tree.

\section{Crop protection}

Partially covering vulnerable portions of the canopy, illumination and scaring frugivorous bats proved to be effective. In sapota and guava orchards at Chettalli, these methods saved $4.5 \%, 6 \%$ and $11 \%$ sapota fruits $(n=$ mean of 75 trees in three replications) respectively. In guava orchards also at Chettalli similar results were obtained. However, the effectiveness of these methods is temporary ( 3 to 4 weeks) and for long term protection, the following crop protection measures are suggested.

1. Buffering the orchards with other fruit trees such as Ficus bengalensis, Ficus glomerata, Ficus religiosa, Ficus benjamina and Ficus mysorensis. The wild fruiting trees such as Careya arborea, Prima species in surrounding farmlands may also be conserved.

2. Block plantation: The orchards may be divided into smaller plots so that they may be covered with sprigs or foliage or thatch or nylon nets.

3. In grape vineyards, covering bunches with dry sprigs of foliage leaving bat damaged bunches on vines itself (Verghese, 1998), control netting and fire crackers (Srinivasulu \& Srinivasulu, 2001) and electric fencing are the methods adopted in Karnataka and Andhra Pradesh to protect grape bunches from bats.

\section{Conservation}

Since bats play important ecological and / or economical roles in evergreen tropical forest tracts, they need to be conserved. Identifying hotspots for bat conservation should also be a priority especially for the Western Ghats region. The Wildlife Protection Act does not afford any level of protection to fruit bats and has categorized them as vermin. Declines in fruit eating bat populations are widespread in India due to high rate of deforestation, increased use of pesticides, degradation of habitats and human consumption.

\section{Conclusion}

The bats, Pteropus giganteus and Cynopterus sphinx were implicated in damaging sapota and guava fruits in hill and coastal regions of Karnataka. The feeding damage to sapota and guava fruits at patches may be economical. Yet, bats may be conserved for their important ecological roles in cultivated ecosystems (Mickleburgh et al., 1992). For bats, forests must be made functional in sustaining their food requirements. People living around forest tracts must not encroach forests for cultivation and must learn to tolerate slight damage to fruits.

\section{Acknowledgement}

Authors are thankful to ICAR, New Delhi for financial support and the encouragement given by the University of Agricultural Sciences, Bangalore is duly acknowledged.

\section{References}

Bates, P.J.J. and D.L.Harrison (1997). Bats of the Indian subcontinent. Harrison Zoological Museum, Kent, U.K., 258pp.

Cox, P.A., E.D. Elmqvist, E.D. Pierson and W.E. Rainey (1991). Flying foxes as strong interactors in South Pacific Island ecosystems: a conservation hypothesis. Conservation Biology 5: 448-454.

Fujita, M.S. and M.D. Turtle (1991). Flying foxes threatened animals of key economic importance. Conservation Biology 5: 455463.

Jacobson, N.H.G. and E. Duplessis (1976). Observations on the ecology and biology of the cape fruit bat in the Eastern Transvaal. South African Journal of Science 72: 270-273.

Mickleburgh, S.P., A.M. Hutson and P.A. Racey (Compilers) (1992). Old World Fruit Bats. An Action Plan for their Conservation. IUCN / SSC Chiroptera Specialist Group, IUCN, Gland, Switzerland. pp.1-16.

Molur, S., G. Marimuthu, C. Srinivasulu, S. Mistry, A.M. Hutson, P.J.J. Bates, S. Walker, K. Padma Priya and A.R. Binu Priya (2002). Status of South Asian Chiroptera -- Conservation Assessment and Management Plan (C.A.M.P.) Workshop Report, 2002. Zoo Outreach Organisation, CBSG South Asia and WILD, Coimbatore, India, viii+141pp+CD-Rom.

Molur, S., P.O. Nameer and S. Walker (1998). Report of the Workshop "Conservation Assessment and Management Plan for Mammals of India. (BCPP-Endangered Species Project)". Zoo Outreach Organization / Conservation Breeding Specialist Group India, Coimbatore, 176pp.

Mistry, S. (2000). Tropical Ecosystems: Structure, Diversity and Human Welfare. In: Ganeshiah, K.S., R. Umashankar and K.S. Bawa (Editors). Proceedings of the International Conference on Tropical Ecosystems. Oxford-IBH, New Delhi. pp.707-710.

Srinivasulu, B. and C. Srinivasulu (2001). Magnitude of depradation on grapes by Short-nosed Fruit Bats Cynopterus sphinx Vahl, 1797 in Secunderabad, India. Current Science 80: 14-15.

Srinivasulu, C. and B. Srinivasulu, (2001). Bats of the subcontinent - an update. Current Science 80: 1378-1380.

Verghese, A. (1998). Non-destructive control of the bat, Cynopterus sphinx (Chiroptera: Pteropodidae) in grapes (Vitis vinifera Linn.) in India. International Journal of Pest Management 44(2): 81-85. 